\title{
Comparison of Public Health Containment Measures of COVID-19 in China and India
}

\author{
Haiqian Chen' \\ Leiyu $\mathrm{Shi}^{2}$ \\ Yuyao Zhang' \\ Xiaohan Wang' \\ Jun Jiao' \\ Manfei Yang' \\ Gang Sun (1D)
}

'Department of Health Management, School of Health Management, Southern Medical University, Guangzhou,

Guangdong, 510515, People's Republic of China; ${ }^{2}$ Department of Health Policy and Management, Bloomberg School of Public Health, Johns Hopkins University,

Baltimore, MD, 2।205, USA
Correspondence: Gang Sun

Department of Health Management, School of Health Management, Southern Medical University, Guangzhou, Guangdong, 5105I5, People's Republic of China

Tel +86 I4103I89758

Email gsun15@jhu.edu;

sunhoney163@I63.com
Objective: This study aimed to make a comparative analysis of the public health containment measures between China and India, explore the causes of the serious COVID-19 epidemic in India, and eventually to improve global infectious disease control.

Methods: We extracted publicly available data from official websites, summarized the containment measures implemented in China and India, and assessed their effectiveness.

Results: China has responded to the COVID-19 outbreak with strict public health containment measures, including lockdown of Wuhan city, active case tracing, and large-scale testing, ultimately preventing a large increase in daily new cases and maintaining a low mortality rate per million population (as of May 5, 2021, daily new cases were 11 and mortality rate per million population was 3.37). India, although imposing a national lockdown to control the pandemic, has not implemented strict testing, tracking, and quarantine measures due to the overburdened healthcare system. Combined with massive lockdown, it has accelerated human mobility and exacerbated the epidemic, resulting in a rapid increase in daily new cases and a high mortality rate per million population (as of May 5, 2021, daily new cases were 412,431 and mortality rate per million population was 166.79 ).

Conclusion: China and India implemented public health containment measures to contain the spread of the COVID-19 pandemic based on their national situations. Meanwhile, daily new cases and mortality of COVID-19 also were affected by environmental and socioeconomic. Countries make a comprehensive strategy not only in terms of the biological, pharmaceutical, health, and sanitation sectors but also based on sustainability science and environmental science.

Keywords: COVID-19, containment measures, China, India, public health

\section{Introduction}

The Coronavirus Disease 2019 (COVID-2019) is an emerging infectious disease caused by the SARS-CoV-2 virus; the first case was detected in the city of Wuhan, Hubei, China, in December 2019. ${ }^{1,2}$ The spread of the COVID-19 formed a global scale quickly and the World Health Organization (WHO) officially characterised the COVID-19 situation as a pandemic on March 11, 2020. ${ }^{3,4}$ As of May 11, 2021, over 159 million confirmed cases of COVID-19 had been reported worldwide, with 3,317,584 deaths. ${ }^{5}$ The COVID-19 pandemic is still ravaging the world, causing serious impacts on the global social economies, transportations, politics and people's lives. ${ }^{6}$ Responding to the COVID-19 pandemic, countries apply containment or mitigation policies based on non-pharmaceutical interventions, including physical distancing, school and store closures, workplace distancing, hand washing, no crowded places, wear the masks, and so on, to delay a significant increase in 
patients and level the demand for hospital beds that alleviate the pressure on the healthcare system. ${ }^{7,8}$

In addition to non-pharmaceutical interventions having a significant impact on the spread of the COVID-19 pandemic, climatological, environmental, demographic, and geographical factors may also influence the spread of COVID-19 in cities. ${ }^{9,10}$ Scholars suggest that air pollution may be one of the factors determining the spread of COVID19 in society, and found that the spread of COVID-19 in cities with high air pollution could result in more COVID19-associated infections and deaths. ${ }^{11-13}$ However, with countries initiating the COVID-19 vaccination programs, some countries begin economic recovery and relax nonpharmaceutical control measures. Combined with the virus mutates, vaccine shortages and lax prevention measures have exacerbated the COVID-19 outbreaks in some countries such as India and Brazil, especially India, which reported a rolling average of 378,000 cases a day, together with more than 222,000 deaths since May 2021. ${ }^{14}$

Moreover, WHO's Tedros Adhanom Ghebreyesus stressed that it was not feasible to control the spread of the epidemic by relying on vaccines alone. In the fight against the COVID-19, basic public health measures were still the foundation, and it will be a mistake to rely on vaccines alone to prevent the epidemic. ${ }^{15}$ On the contrary, China, which was first affected by the epidemic, successfully contained the large-scale spread of the epidemic through a series of non-pharmaceutical control measures without a vaccine, and gradually restored its economy and people's normal lives. ${ }^{16}$ And with the arrival of the vaccine, China is still implementing strict public health measures, such as temperature monitoring in public places and wearing face masks, while promoting nationwide vaccination of the COVID-19 vaccine.

Responding to the still serious COVID-19 pandemic, this paper will make a comparative analysis of the situation of China and India as well as the public health prevention and control measures implemented, and explore the causes of the serious COVID-19 epidemic in India. We hope these findings could provide some useful references and suggestions for countries experiencing the severe impact of the COVID-19 epidemic.

\section{Methods}

\section{Research Setting}

This study focuses on making a comparison analysis of public health containment measures of COVID-19 in China and India between January 1, 2020 and May 5, 2021. China was the first large Asian country to experience a rapid increase in COVID-19-related confirmed cases and deaths in the first wave of the outbreak. India also was a large Asian country to experience a rapid increase in COVID-19-related confirmed cases and deaths in the first and second wave of the outbreak. We accessed the effectiveness of containment measures combined with their situation of epidemic.

\section{Data and Sources}

Period under the study is from January 1, 2020 to May 5, 2021, and all epidemiological data were obtained from National Health Commission of the People's Republic of China, Johns Hopkins University \& Medicine Coronavirus Resource Center and Worldometer. ${ }^{17-19}$ Data indicators include national population, total confirmed cases, daily new cases, total deaths, and daily new deaths. For policy information, we searched national documents and responses to COVID-19 through various countries' government web-page, such as media announcements and governmental decrees of China and India.

\section{Results}

\section{China's Approaches to Response the COVID-19 Pandemic}

As the first country affected by the COVID-19 epidemic, China has included COVID-19 as a national category $B$ infectious disease and established a strong epidemic command system in response to the epidemic. With the new confirmed cases rapidly increasing, the government adopted unprecedented large-scale public health measures, putting Wuhan city on lockdown on January 23, 2020, subsequently imposing a nationwide screening and classification of centralized management "four categories of personnel", strictly abiding by the principle of "four early". These containment measures isolated the source of infection and cut off the spread of the virus. To alleviate the Hospital Runs, Chinese authorities mobilized health care workers to support Hubei province and implemented the plan of "Pairing assistance" to contain the spread of the epidemic throughout the country. On April 8, 2020, Wuhan lifted the lockdown, and the epidemic prevention and control battle achieved significant results. Since April 29, 2020, China's epidemic prevention and control have entered a normal stage, with clusters of sporadic cases occurring in some areas and cases imported from abroad basically under control. Table 1 shows the major public health containment measures in China. 
Table I The Major Public Health Containment Measures in China

\begin{tabular}{|c|c|c|}
\hline SN & Policies & Containment Measures \\
\hline 1 & Classification of infectious diseases & $\begin{array}{l}\text { On Jan } 20,2020 \text {, the SARS-Cov- } 2 \text { included in the national category B infectious disease, and } \\
\text { the response model of category } A \text { infectious diseases and direct network reporting. }\end{array}$ \\
\hline 2 & Lockdown of Wuhan city & $\begin{array}{l}\text { On Jan } 23,2020 \text {, lockdown of Wuhan city was implemented. All airports, railway stations, } \\
\text { ferries in Wuhan were closed and it required people to be quarantined at home. Wuhan lifted } \\
\text { lockdown on April } 8 \text {. }\end{array}$ \\
\hline 3 & $\begin{array}{l}\text { Establishing an outbreak command } \\
\text { system }\end{array}$ & $\begin{array}{l}\text { On Jan } 25,2020 \text {, Chinese central government established a leading group to response the } \\
\text { COVID-19 pandemic and dispatched leading groups to Hubei province and other hard-hit } \\
\text { areas guide to their works. }\end{array}$ \\
\hline 4 & $\begin{array}{l}\text { Classified management of "four } \\
\text { categories of personnel" }\end{array}$ & $\begin{array}{l}\text { (I) On Feb 2, 2020, Wuhan city implemented the "four categories of personnel"- - confirmed } \\
\text { patients, suspected patients, febrile patients, and close contacts - for centralized } \\
\text { management. } \\
\text { (2) Based on the community grid, screening the "four categories of people" nationwide to } \\
\text { collect accurate case data. }\end{array}$ \\
\hline 5 & $\begin{array}{l}\text { Strictly abide by "four early's" } \\
\text { principles }\end{array}$ & $\begin{array}{l}\text { (I) On Feb 3, 2020, President Xi Jinping noted to further strengthen the COVID-19 } \\
\text { prevention and control, and strictly abided by the "four early's" principles - early detection, } \\
\text { early reporting, early isolation, and early treatment - to improve admission and cure rates } \\
\text { and reduce infection and death rates. }\end{array}$ \\
\hline 6 & Healthcare measures & $\begin{array}{l}\text { (I) Mobilizing medical resources nationwide to fully support the medical treatment in Hubei } \\
\text { province. Between Jan } 24 \text { and March } 8,2020 \text {, a total of } 346 \text { national medical teams, } 42,600 \\
\text { medical personnel and more than } 900 \text { public health personnel to assist Hubei. } \\
\text { (2) On Feb I3, China adopted nationwide "pairing assistance" measure with at least one } \\
\text { province assisting one city to alleviate pressure in the most severe area. } \\
\text { (3) On Feb 5, 2020, makeshift hospitals in operation. } 16 \text { Fangcang shelter hospitals with more } \\
\text { than } 14,000 \text { beds was built in more than } 10 \text { days, a 1000-bed Huoshenshan Hospital was built } \\
\text { in } 10 \text { days, and a 1600-bed Leishenshan Hospital was built in } 12 \text { days. } \\
\text { (4) The central government cooperated with local governments and enterprises to distribute } \\
\text { more medical supplies and daily necessities to Hubei to ensure the normal operation of } \\
\text { society. }\end{array}$ \\
\hline 7 & Community and social measures & $\begin{array}{l}\text { (I) On Jan } 29,2020 \text {, raising the public health emergency response to the highest level in all } \\
\text { localities. } \\
\text { (2) Temperature checkpoints were set up across the country. } \\
\text { (3) Taking effective measures to avoid people gathering and cross-infection: extend the Spring } \\
\text { Festival holiday, cancel or postpone gathering activities, postpone reopening schools in an } \\
\text { orderly manner; close entertainment venues; public service places that need to be opened } \\
\text { must take body temperature and wear masks; encourage employees to telecommute. } \\
\text { (4) Implementing community closed management nationwide. Residents entering and leaving } \\
\text { the community needed to register and check their body temperature. } \\
\text { (5) Extensive public education in community were imposed for residents. } \\
\text { Residents consciously abided by public health requirements such as home isolation and I4 } \\
\text { days after cross-regional travel, strictly implement health living habits such as wearing masks, } \\
\text { social distancing, and reducing gathering. }\end{array}$ \\
\hline
\end{tabular}

(Continued) 
Table I (Continued).

\begin{tabular}{|c|c|c|}
\hline SN & Policies & Containment Measures \\
\hline 8 & $\begin{array}{l}\text { Epidemic prevention and control } \\
\text { enter into normal stage }\end{array}$ & $\begin{array}{l}\text { Preventing imported cases from abroad: } \\
\text { (I) Nucleic acid testing was required for all travelers or returning residents entering from al } \\
\text { ports of entry. They will be released from quarantine if they do not present with symptoms } \\
\text { and are tested negative for SARS-CoV-2 after } 14 \text { days of quarantine. } \\
\text { (2) Fully implementing the health declaration system for people exit and entry, strictly } \\
\text { carrying out entry health quarantine, and suspending the entry of foreigners with valid } \\
\text { Chinese visas and residence permits. } \\
\text { Preventing domestic COVID-19 cases rebound: } \\
\text { (I) Implementing a region-specific, multi-level targeted approach for epidemic prevention and } \\
\text { control strategies nationwide, and classifying different levels with low-, medium-, high-risk } \\
\text { levels. } \\
\text { (2) Implementing health code, with color as identification mark, as the voucher of travel, } \\
\text { return to work, daily life and access to public places. } \\
\text { Accelerating vaccines development and public vaccination: } \\
\text { (I) In December } 2020 \text {, six domestic COVID-19 vaccines had entered Phase III clinical trials, } \\
\text { and initiated vaccination for key populations. } \\
\text { (2) The free vaccination campaign was launched in February } 2021 \text {, and more } 620 \text { million } \\
\text { doses of vaccine had been administered by May } 31 \text {. }\end{array}$ \\
\hline
\end{tabular}

\section{India's Approaches to Response the COVID- 19 Pandemic}

The first case of COVID-19 in India was reported from Kerala on Jan 30, 2020, a month after its detection in China. In response to the outbreak, India quickly implemented strict border control measures in the early stages and imposed a nationwide lockdown from March 25, 2020, until June 2020. Starting on June 8, 2020, the Indian government adopted a phased "unblocking" policy to economic recovery, which extended into November 2020. As containment measures were relaxed across the country, the number of COVID19 diagnoses climbed to become the second-largest confirmed in the world by January 2021. Table 2 shows the major public health containment measures in India.

\section{Epidemiological Trends and Population Mortality Rates of COVID-19 in China and India}

As shown in Figure 1, the COVID-19 epidemic response in China was divided into three main phases: the initial phase, the rapid spreading phase, and the ongoing prevention and control phase. In the initial phase, the new daily COVID-19 cases were low and the mortality rate per million population was only under 0.012. During the rapidly spreading phase, China actively screened and proactively identified and tracked cases; the new daily COVID-19 cases rapidly increased to a maximum of 15,136 cases, and the mortality rate per million population rose to 3.222. After implementing a slew of non-pharmaceutical interventions, China has entered an ongoing prevention and control phase since April 29, 2020; the new daily COVID-19 cases decreased, and the mortality rate per million population remained at 3.37 as of May 5, 2021.

Figure 2 shows that India's response to the COVID-19 outbreak was divided into four stages: the early phase of the epidemic, the epidemic spreading, the first wave of the epidemic, and the second wave of the epidemic. In the early stage, the new daily cases were low and the mortality per million population was only 0.02 . During the epidemic spreading, the new daily cases and the mortality rate per million population continuously rose with 61,242 cases and 26.46 as of July 31 , 2020. In stage 3 , the daily new cases increased and then decreased, but the mortality rate per million population continuously rising reached 107.78. In stage 4, with the nonpharmaceutical interventions relaxed and economic recovery, the daily new cases and the mortality rate per million population increased rapidly than before; the new daily cases were 412,431 and the mortality rate per million population was 166.79 on May 5, 2021.

Figure 3 shows the trend of total cases in China and India. China's epidemic outbreak mainly concentrated in the early phase; after China adopted strict city closure measures, aggressive screening, and tracking of detected cases, the outbreak was effectively controlled, with a slow 
Table 2 The Major Public Health Containment Measures in India

\begin{tabular}{|c|c|c|}
\hline $\mathbf{S N}$ & Policies & Containment Measures \\
\hline 1 & Border control measures & $\begin{array}{l}\text { (I) On January } 25,2020 \text {, the government issued a travel warning, asking the public to avoid non- } \\
\text { essential travel to China. } \\
\text { (2) On February 2, electronic visa applications for Chinese citizens and foreign residents in China were } \\
\text { suspended. } \\
\text { (3) On March II, the border was closed. From March I } 3 \text { to April I5, except for special visa categories, } \\
\text { all travel visas to India for foreigners have been temporarily suspended immediately and then extended } \\
\text { to May } 3 \text {. } \\
\text { (4) From March } 22 \text { to 29, banning all international flights entering the country, } \\
\text { (5) A mandatory I4-day quarantine was imposed on travellers from the worst-affected countries. }\end{array}$ \\
\hline 2 & Health care measures & $\begin{array}{l}\text { (I) On Jan 3I, 2020, according to a notice posted on the DGTI website, India has banned export the } \\
\text { personal protective equipment (PPE) such as face masks and protective clothing during the COVID-I9 } \\
\text { epidemic. } \\
\text { (2) On } 4 \text { March, restricting the export of } 26 \text { active pharmaceutical ingredients (APIs) and medicines. On } \\
\text { March I7, nearly } 60,000 \text { isolation beds were set up across the country. On March } 31 \text {, about 20,000 train } \\
\text { carriages have been modified for the isolation of patients diagnosed with COVID-19. } \\
\text { (3) On June I2, the Indian government raised testing capacity in New Delhi and increased hospital beds, } \\
\text { including thousands in converted train cars. On } 27 \text { June, the Fangcang shelter hospital was built located } \\
\text { on the Bangalore International Exhibition Centre (IBC), and it was closed on September } 4 \text {. } \\
\text { (4) On I August, the Sanjivan mobile phone application was launched for registering home quarantines, } \\
\text { checking the availability of hospital beds and requesting an ambulance, as well as calling a dedicated } \\
\text { hotline number for remote consultations. } \\
\text { (5) On March } 25,202 \text { I, delaying the COVID-19 Vaccine Implementation Plan (COVAX) and restricting } \\
\text { the export of vaccines. }\end{array}$ \\
\hline 3 & $\begin{array}{l}\text { Lockdown country/city } \\
\text { in five stages }\end{array}$ & $\begin{array}{l}\text { (I) From March } 25 \text { to April 14, 2020, a strict nationwide lockdown was imposed, closing all stores, } \\
\text { commercial establishments, factories, offices, markets and places of worship and suspending all non- } \\
\text { essential activities. } \\
\text { (2) From April I5 to May 3, 2020, districts were divided into zones using a colour-coded tier system } \\
\text { based on incidence rates, classified as a "Red" (hotspot), "Orange", or "Green" (little to no } \\
\text { transmission) zone. } \\
\text { (3) From May } 4 \text { to I7, the states were divided into three zones: red, orange and green. I } 30 \text { red zones } \\
\text { were under strict control, while } 280 \text { orange and } 319 \text { green zones were appropriately liberalized for } \\
\text { related activities. The red and orange zones were subject to a strict "stay-at-home order", while people } \\
\text { in the green zones can travel more freely. } \\
\text { (4) Phase } 3 \text { and } 4 \text { of the lockdown extended till } 3 \text { I May, with incremental relaxations and changes. } \\
\text { (5) From June I to 30, a nationwide curfew was imposed from 9pm to 5pm on the following day, with } \\
\text { this phase of the lockdown divided into tightly controlled and non-tightly controlled areas. }\end{array}$ \\
\hline 4 & Public health measures & $\begin{array}{l}\text { (I) On April 9, 2020, several states, including New Delhi and Mumbai, introduced mandatory rules that } \\
\text { all people must wear masks when going out. } \\
\text { (2) From May I8 to May } 3 \text { I, a nationwide curfew was imposed from 19:00 to 7:00 a.m. on the } \\
\text { following day. People were prohibited from going out except for essential needs. } \\
\text { (3) The government has advised all states to require physical establishments such as factories and shops } \\
\text { in their states to adopt a "Work From Home Policy" and pay wages as usual. } \\
\text { (4) On February 20, 202I, Mumbai issued an anti-epidemic regulation: if five or more COVID-19 cases } \\
\text { were confirmed in a residential building, the entire residential building will be closed down and all } \\
\text { residents in the building will be required to stay indoors in isolation. } \\
\text { (5) March } 25,202 \text { I, prohibiting mass celebrations during the traditional holiday of Holi. } \\
\text { (6) On April } 6,202 \text { I, New Delhi imposed a curfew from 22:00 to 5:00 on the following day. During the } \\
\text { curfew, only shops providing essential services were allowed to operate. Vehicles were not allowed to } \\
\text { be used unless dealing with emergency matters. }\end{array}$ \\
\hline
\end{tabular}

(Continued) 
Table 2 (Continued).

\begin{tabular}{|c|c|c|}
\hline SN & Policies & Containment Measures \\
\hline 5 & $\begin{array}{l}\text { Lifting restrictions in } \\
\text { stages }\end{array}$ & $\begin{array}{l}\text { The country began a phased lifting of restrictions on } 8 \text { June. This phased lifting of restrictions continued } \\
\text { in a series of "unlocks" which extended into November } 2020 \text {. } \\
\text { (I) From June } 8,2020 \text {, religious sites, hotels, restaurants, and shopping centers in India will be opened; } \\
\text { the curfew will be adjusted to 9:00 p.m. to 5:00 a.m.; and cross-border traffic between states will be } \\
\text { free. } \\
\text { (2) On July I, 2020, it was announced that educational institutions, subway services, and large gatherings } \\
\text { would continue to be suspended and the daily curfew would be reduced by one hour. Schools will } \\
\text { remain closed until July } 3 \text { I. } \\
\text { (3) On August I, more activities were held outside the quarantine zone, but inside was tightly } \\
\text { controlled, while individual curfews have been lifted. Schools and educational institutions will remain } \\
\text { closed until August } 3 \text { I. } \\
\text { (4) On September I, workplaces, public transportation, restaurants, gyms and other places were } \\
\text { reopened to restore the economy. } \\
\text { (5) On October I5, except for controlled areas, cinemas and theatres can resume business, but the } \\
\text { number of consumers should not exceed 50\% of the approved number, and places such as } \\
\text { entertainment and parks can be open to the public. }\end{array}$ \\
\hline 6 & $\begin{array}{l}\text { COVID-19 vaccination } \\
\text { measure }\end{array}$ & $\begin{array}{l}\text { (I) On January } 3,202 I \text {, the emergency use of Covishield and Covaxin vaccine was officially approved. } \\
\text { (2) On } 16 \text { January } 202 I \text {, India launched the world's largest vaccination campaign, with nurses, doctors } \\
\text { and other frontline workers being given priority for vaccination. } \\
\text { (3) As of } 29 \text { May } 202 I \text {, India has administered } 212,066,614 \text { doses overall, including first and second } \\
\text { doses of the currently-approved vaccines. }\end{array}$ \\
\hline
\end{tabular}

increase in COVID-19 cases. In contrast, India's epidemic outbreak has not been well controlled and the COVID-19 cases kept continually raising, although a series of strict non-pharmaceutical measures have been taken, such as sealing off cities and countries, and home quarantine. But these measures have not been strictly enforced, which is one of the reasons why the second wave of the outbreak is more serious than the first.

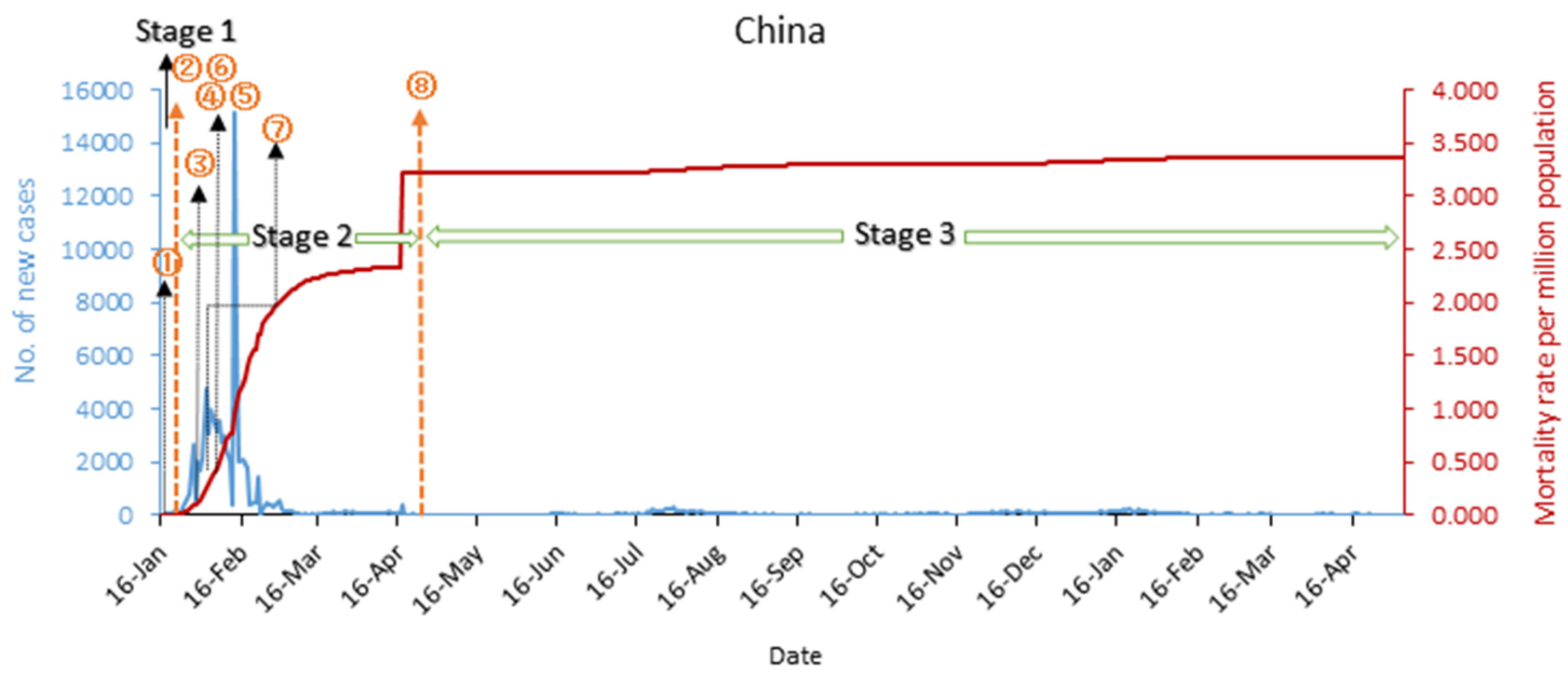

Figure I China's COVID-19 epidemic curves and mortality rate per million population.

Notes: Stage I: before Jan 23, 2020, the initial phase of the epidemic. (1) On Jan 20, 2020, classification of infectious diseases. Stage 2: between April 4 to 28 , the rapid spread of the epidemic. (2) On Jan 23, 2020, lockdown Wuhan city; (3) On Jan 25, 2020, establishing an outbreak command system; (4) On Feb 2, 2020, classified management of "four categories of personnel"; (5) On Feb 3, 2020, strictly abide by "four early's" principles; (6) Since Jan 23, 2020, healthcare measures; (7) On Jan 29, 2020, community and social measures. Stage 3: since April 29, the ongoing prevention and control phase. (8) Epidemic prevention and control enter into normal stage. 


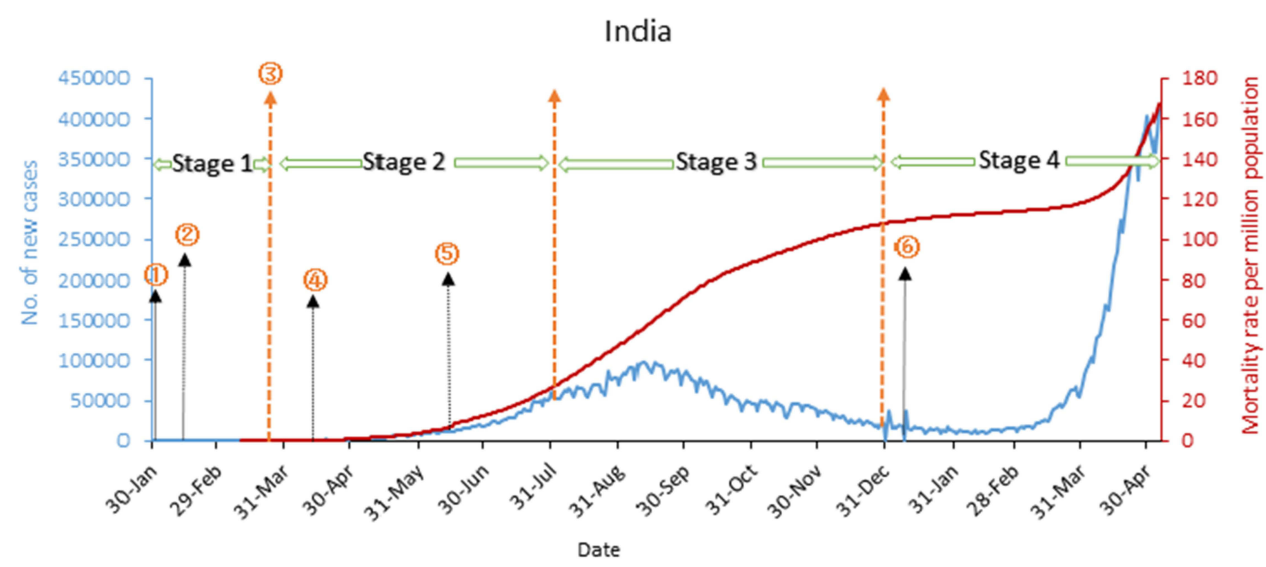

Figure 2 India's COVID-19 epidemic curve and mortality rate per million population.

Notes: Stage I: before March 25, 2020, the early phase of the epidemic. (1)Since January 25, 2020, border control measures; (2)Since January 31 , 2020, healthcare measures. Stage 2: from March 25 to July 3I, the epidemic spreading. (3)From March 25 to June 30, 2020, lockdown country/city in Five stages; (4) Since April 9, 2020, public health measures. Stage 3: from August I to December 3I, the first wave of the epidemic peak. (5)Since June 8, 2020, lifting restrictions in stages. Stage 4: from Jan I to May 6, 202I, the second wave of the epidemic peak. (6) Since January 3, 2021, COVID-19 vaccination measure.

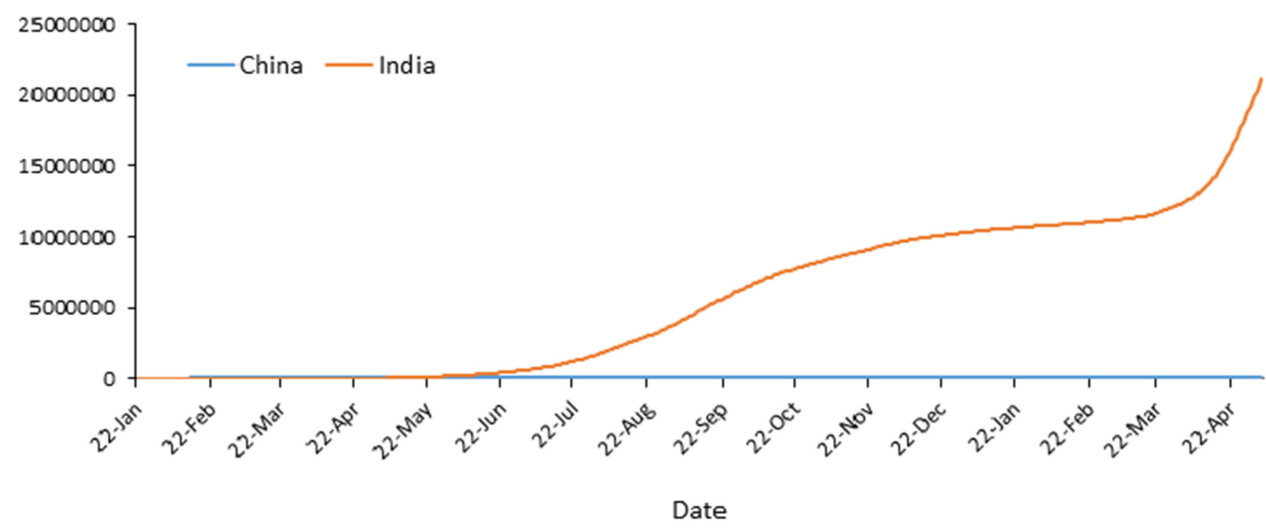

Figure 3 The trend of the COVID-19 total cases in China and India.

\section{Discussion}

This study presented a series of public health measures taken in China and India during the response to the COVID-19 outbreak, and the effectiveness of these measures on daily new cases and mortality rate per million population. With growing evidence for the effectiveness of public health interventions to control the transmission of the COVID-19 pandemic, ${ }^{20-23}$ different countries have adopted different public health interventions at different stages to deal with pandemics based on their national conditions. However, with the introduction of the vaccine and the global economic recovery, some countries have seen a rapid increase in new COVID-19 cases, such as the United States, Brazil, India, and other countries, especially India, where the new daily cases reach more than 300,000 per day. On the contrary, there are some countries with better control of the epidemic, such as China, South Korea, Singapore, and other Asian countries.

China was the first country to experience the COVID-19 outbreak, and during the initial phase of the outbreak, there was some community transmission and Hospital Runs in Wuhan city due to inexperience in responding to the outbreak. ${ }^{24}$ However, the response was subsequently adjusted to a combination of "home isolation" and "community prevention and control", and establishing "centralized isolation sites" for prevention and treatment. In terms of medical treatment, "designated hospitals" and new "temporary hospitals" were designated to expand the supply capacity of medical services. Through concerted efforts in both epidemic prevention and treatment, the government achieved zero growth of new COVID-19 patients in Wuhan within two months. Furthermore, scholar suggests that the 
national emergency response appears to have delayed the growth of the COVID-19 epidemic in China and limited the size of the epidemic, avoiding hundreds of thousands of cases by February 19, 2020 (day 50). ${ }^{25}$

In addition, China adopted different containment measures in different stages. At the beginning of the outbreak, China classified the category of infectious diseases. During the rapidly moving upward of the epidemic, China imposed a strict containment strategy, such as lockdown of Wuhan city, and was proactive in finding and managing "four categories of personnel" - confirmed cases, presumptive cases, fever cases, and close contacts. ${ }^{26}$ Studies show that traffic restrictions and quarantine measures' combination in Wuhan stemmed the local epidemic growth, and the strict control measures adopted in China significantly mitigated the spread of COVID-19. ${ }^{27,28}$ As the COVID-19 epidemic is continuously ongoing, China is preventing a rebound in domestic cases of COVID-19 while also preventing and controlling the COVID-19 imported cases. Although China has since had sporadic outbreaks of COVID-19 in several areas, including Beijing and Qingdao, they were all contained.

India, like China, implemented strict containment measures after the first case of COVID-19 was detected. In terms of border prevention and control, the government's response to the pandemic was through a series of travel advisories and initiation of screening for fever of incoming international travelers at ports of entry. Asymptomatic passengers were screened, home quarantined, and followed up, while those with symptoms were tested and if positive, isolated, and provided care. ${ }^{29}$ Moreover, to contain the virus spread, a nationwide lockdown was imposed on March 24, 2020, which lasted until June. ${ }^{30}$ At the same time, temporary isolation beds were set up to alleviate medical runs, drawing on the experience of China's Fangcang shelter hospitals. India was successful in limiting the number of cases and the pandemic grew slowly in the initial phase with these strict containment measures. However, with the economic recovery, the lockdown was gradually eased. Millions of stranded migrant workers left industrialized western regions of the country to the northern and eastern countryside once the domestic travel restriction was waived off. ${ }^{31}$ This, combined with a large religious event of the Kumbh Mela in April 2021, which gathered more than 25,000 people, made the second wave of the epidemic more severe than the first.

Both China and India have taken strict containment measures to control the epidemic by aggressively identifying and tracking cases, locking down infected areas (lockdown countries/cities), and expanding quarantine beds. ${ }^{32-34}$ However, while China has managed to control the spread of the epidemic with the same containment measures from "Hospital runs" to "Health Care for All", India does not seem to be able to contain the spread of the epidemic. The reasons for this were fourfold: virus mutation, medical runs, vaccination, and relaxed vigilance. India must now adopt a two-pronged strategy. First, the botched vaccination campaign must be rationalized and implemented as soon as possible. Second, India must roll out the vaccine while minimizing the spread of SARS-CoV-2. ${ }^{14}$

This study mainly focuses on the comparative analysis of public health containment policies implemented in China and India to assess the effectiveness of epidemic prevention and control. However, there is a limitation in this study; some factors have not been considered when assessing the effectiveness of the public health containment measures, such as the country's GDP per capita, healthcare expenditure, air pollution, ${ }^{35-37}$ human mobility and poverty, ${ }^{38}$ and some control measures in hospitals also affect the confirmed cases and mortality of COVID$19 .^{39-41}$

\section{Conclusion}

China and India implemented public health containment measures to contain the spread of the COVID-19 pandemic based on their national situations. As far as China and India are concerned, China has been relatively successful in containing the spread of the COVID-19 outbreak, especially in case tracking, mass testing, and improving treatment capacity. Meanwhile, daily new cases and mortality of COVID-19 also were affected by environmental and socioeconomic situations. Countries make a comprehensive strategy not only in terms of the biological, pharmaceutical, health, and sanitation sectors but also based on sustainability science and environmental science. ${ }^{11}$

\section{Data Sharing Statement}

All data generated or analyzed during this study are included in this published article.

\section{Ethics Approval and Consent to Participate}

Not applicable. 


\section{Consent for Publication}

Not applicable.

\section{Acknowledgments}

The authors gratefully acknowledge the financial supports of the National Social Science Fund of China (No. 16BGL184), and thank all study participants who have been involved and contributed to the procedure of data collection.

\section{Disclosure}

The authors have no conflicts of interest to declare for this work.

\section{References}

1. Coccia M. The relation between length of lockdown, numbers of infected people and deaths of Covid-19, and economic growth of countries: lessons learned to cope with future pandemics similar to Covid-19 and to constrain the deterioration of economic system. Sci Total Environ. 2021;775:145801.

2. Maude RR, Jongdeepaisal M, Skuntaniyom S, et al. Improving knowledge, attitudes and practice to prevent COVID-19 transmission in healthcare workers and the public in Thailand. BMC Public Health. 2021;21(1):749. doi:10.1186/s12889-021-10768-y

3. Kwok CYT, Wong MS, Chan KL, et al. Spatial analysis of the impact of urban geometry and socio-demographic characteristics on COVID-19, a study in Hong Kong. Sci Total Environ. 2021;764:144455. doi:10.1016/j.scitotenv.2020.144455

4. Rosario DKA, Mutz YS, Bernardes PC, Conte-Junior CA. Relationship between COVID-19 and weather: case study in a tropical country. Int J Hyg Environ Health. 2020;229:113587. doi:10.1016/j.ijheh.2020.113587

5. COVID-19 coronavirus pandemic. Available from: https://www. worldometers.info/coronavirus/. Accessed August 4, 2021.

6. Wang L, Xu C, Wang J, Qiao J, Yan M, Zhu Q. Spatiotemporal heterogeneity and its determinants of COVID-19 transmission in typical labor export provinces of China. BMC Infect Dis. 2021;21 (1):242. doi:10.1186/s12879-021-05926-x

7. Bedford J, Enria D, Giesecke J, et al. COVID-19: towards controlling of a pandemic. Lancet. 2020;395(10229):1015-1018. doi:10.1016/ S0140-6736(20)30673-5

8. Coccia M. The effects of atmospheric stability with low wind speed and of air pollution on the accelerated transmission dynamics of COVID-19. Int J Environ Studies. 2020;78(1):1-27. doi:10.1080/ 00207233.2020 .1802937

9. Coccia M. How do low wind speeds and high levels of air pollution support the spread of COVID-19? Atmos Pollut Res. 2021;12 (1):437-445. doi:10.1016/j.apr.2020.10.002

10. Sunyer J, Dadvand P, Foraster M, Gilliland F, Nawrot T. Environment and the COVID-19 pandemic. Environ Res. 2021;195:110819. doi:10.1016/j.envres.2021.110819

11. Coccia M. Factors determining the diffusion of COVID-19 and suggested strategy to prevent future accelerated viral infectivity similar to COVID. Sci Total Environ. 2020;729:138474. doi:10.1016/j. scitotenv.2020.138474

12. Coccia M. An index to quantify environmental risk of exposure to future epidemics of the COVID-19 and similar viral agents: theory and practice. Environ Res. 2020;191:110155. doi:10.1016/j.envres.2020.110155
13. Coccia M. Effects of the spread of COVID-19 on public health of polluted cities: results of the first wave for explaining the deja vu in the second wave of COVID-19 pandemic and epidemics of future vital agents. Environ Sci Pollut Res Int. 2021;28(15):19147-19154. doi:10.1007/s11356-020-11662-7

14. The L. India's COVID-19 emergency. Lancet. 2021;397 (10286):1683. doi:10.1016/S0140-6736(21)01052-7

15. WHO director-general's opening remarks at the media briefing on COVID-19; 2021. Available from: https://www.who.int/directorgeneral/speeches/detail/who-director-general-s-opening-remarks-atthe-media-briefing-on-covid-19-1-march-2021. Accessed August 4, 2021.

16. Lu G, Razum O, Jahn A, et al. COVID-19 in Germany and China: mitigation versus elimination strategy. Glob Health Action. 2021;14 (1):1875601. doi:10.1080/16549716.2021.1875601

17. Johns Hopkins university coronavirus resource center. Available from: https://coronavirus.jhu.edu/?from=groupmessage. Accessed August 4, 2021.

18. National health commission of the People's Republic of China. Updates on the epidemic. Available from: http:/www.nhc.gov.cn/ xcs/yqtb/list_gzbd.shtml. Accessed August 04, 2021.

19. COVID-19 coronavirus pandemic; 2020. Available from: https:// www.worldometers.info/coronavirus/\#countries. Accessed August 4, 2021.

20. Lai S, Ruktanonchai NW, Zhou L, et al. Effect of non-pharmaceutical interventions for containing the COVID-19 outbreak in China. medRxiv. 2020.

21. Liu W, Yue XG, Tchounwou PB. Response to the COVID-19 epidemic: the Chinese experience and implications for other countries. Int J Environ Res Public Health. 2020;17(7).

22. Maier BF, Brockmann D. Effective containment explains subexponential growth in recent confirmed COVID-19 cases in China. Science. 2020;368(6492):742-746. doi:10.1126/science.abb4557

23. Jeong GH, Lee HJ, Lee J, et al. Effective control of COVID-19 in South Korea: cross-sectional study of epidemiological data. J Med Internet Res. 2020;22(12):e22103. doi:10.2196/22103

24. Wanyi C, Chao H. Strategic hospital runs; 2020.

25. Tian H, Liu Y, Yidan L, et al. An investigation of transmission control measures during the first 50 days of the COVID-19 epidemic in China. Science. 2020;368:638-642. doi:10.1126/science.abb6105

26. The L. China's response to COVID-19: a chance for collaboration. Lancet. 2021;397(10282):1325. doi:10.1016/S0140-6736(21)00823-0

27. Liang J, Yuan HY, Wu L, Pfeiffer DU. Estimating effects of intervention measures on COVID-19 outbreak in Wuhan taking account of improving diagnostic capabilities using a modelling approach. BMC Infect Dis. 2021;21(1):424. doi:10.1186/s12879-021-06115-6

28. Moritz U, Kraemer G, Yang C-H, et al. The effect of human mobility and control measures on the COVID-19 epidemic in China. Science. 2020;368:397-493. doi:10.1126/science.abb4218

29. Kumar S, Reddy DCS. Response to COVID-19 pandemic in India how can we strengthen our response. Indian J Commun Med. 2020;45 (3):251-255. doi:10.4103/ijcm.IJCM_653_20

30. Mukherjee S. Disparities, desperation, and divisiveness: coping with COVID-19 in India. Psychol Trauma Theory, Res, Practice Policy. 2020;12(6):582-584. doi:10.1037/tra0000682

31. Quadri SA, Padala PR. An aspect of kumbh mela massive gathering and COVID-19. Current Trop Med Rep. 2021;1-6.

32. Chen H, Shi L, Zhang Y, Wang X, Sun G. A cross-country core strategy comparison in China, Japan, Singapore and South Korea during the early COVID-19 pandemic. Global Health. 2021;17 (1):22. doi:10.1186/s12992-021-00672-w

33. Chinazzi M, Davi JT, Ajelli M, et al. The effect of travel restrictions on the spread of the 2019 novel coronavirus (COVID-19) outbreak. Science. 2020;368:395-400. doi:10.1126/science.aba9757 
34. Arinaminpathy N, Das J, McCormick TH, Mukhopadhyay P, Sircar N. Quantifying heterogeneity in SARS-CoV-2 transmission during the lockdown in India. Epidemics. 2021;36:100477. doi:10.1016/j.epidem.2021.100477

35. How CM. (Un)sustainable environments are related to the diffusion of COVID-19: the relation between coronavirus disease 2019, air pollution, wind resource and Energy. Sustainability. 2020;12(22):9709.

36. Coccia M. The impact of first and second wave of the COVID-19 pandemic in society: comparative analysis to support control measures to cope with negative effects of future infectious diseases. Environ Res. 2021;197:111099. doi:10.1016/j.envres.2021.111099

37. Coccia M. High health expenditures and low exposure of population to air pollution as critical factors that can reduce fatality rate in COVID-19 pandemic crisis: a global analysis. Environ Res. 2021;199:111339. doi:10.1016/j.envres.2021.111339

38. Yechezkel M, Weiss A, Rejwan I, Shahmoon E, Ben-Gal S, Yamin D. Human mobility and poverty as key drivers of COVID-19 transmission and control. BMC Public Health. 2021;21(1):596. doi:10.1186/ s12889-021-10561-x
39. Tiao CH, Tsai LC, Chen LC, Liao YM, Sun LC. Healthcare failure mode and effect analysis (HFMEA) as an effective mechanism in preventing infection caused by accompanying caregivers during COVID-19-experience of a city medical center in Taiwan. Qual Manag Health Care. 2021;30(1):61-68. doi:10.1097/ QMH.0000000000000295

40. Gola M, Caggiano G, De Giglio O, et al. SARS-CoV-2 indoor contamination: considerations on anti-COVID-19 management of ventilation systems, and finishing materials in healthcare facilities. Ann Ig. 2021;33(4):381-392.

41. Russell FM, Wang A, Ehrman RR, Jacobs J, Croft A, Larsen C. Risk factors associated with hospital admission in COVID-19 patients initially admitted to an observation unit. Am J Emerg Med. 2020.
Risk Management and Healthcare Policy

\section{Publish your work in this journal}

Risk Management and Healthcare Policy is an international, peerreviewed, open access journal focusing on all aspects of public health, policy, and preventative measures to promote good health and improve morbidity and mortality in the population. The journal welcomes submitted papers covering original research, basic science, clinical \& epidemiological studies, reviews and evaluations,

\section{Dovepress}

guidelines, expert opinion and commentary, case reports and extended reports. The manuscript management system is completely online and includes a very quick and fair peer-review system, which is all easy to use. Visit http://www.dovepress.com/testimonials.php to read real quotes from published authors. 